\title{
Analysis on the Inheritance Path of Henan Handicraft in the Construction of New Rural Culture
}

\author{
Huanan Shang \\ College of Art and Design \\ Huanghe Science and Technology University \\ Zhengzhou, China
}

\begin{abstract}
The construction of a new socialist countryside is a systematic project, while "the construction of new rural culture" is the spirit of new rural construction and it is also the key and difficult point of new rural construction. There are rich folk handicraft resources in the countryside of Henan and it is significant for the construction of new rural culture in Henan province about how to protect, inherit and carry forward the folk arts and crafts in the current situation.
\end{abstract}

Keywords—new rural culture construction; folk arts and crafts; regional economy

\section{INTRODUCTION}

The construction of a new socialist countryside is a systematic project covering economic construction, political construction and cultural construction. "New rural culture construction" is the soul of the new rural construction in the four aspects. At the same time, it is also the key and difficult point in the new rural construction.

Farmers play an important role in the construction of new socialist countryside as the main body of the new rural construction. In a large number of studies on folk arts and crafts, there are a few researches on the combination of folk handicrafts and new rural cultural construction in Henan. Take stock of cultural and artistic context of China, especially the places retained culture and art with Chinese characteristics are generally in rural areas. This is particularly prominent in Henan. Henan Province has been known as "the birthplace of Chinese civilization." There are rich folk handicraft resources in the countryside of Henan. It has great significance for the construction of new rural culture in Henan province about how to protect, inherit and carry forward the folk arts and crafts in the current situation.

\section{THE PRESENT SitUATION OF RURAL HANDICRAFTS IN HENAN PROVINCE}

Folk handicrafts are the material and cultural remains of the folk life culture created, wanted and inherited by the broad masses of people. In general, the most basic requirement of handicrafts and their products is that it can facilitate life and beautify and enrich life. The different needs are handicrafts and their products have diversified appearance. The handicraft

This paper is the result of humanities and social science research project of Henan province education department. Item number: 2012-QN-297 products of different materials and different means have played a huge role in people's lives in different historical periods. This has become an important part of traditional culture.

The rural handicrafts in Henan have a unique advantage. Henan is one of the birthplaces of Chinese civilization. There are folk arts and crafts represented by Bian embroidery, Jun porcelain, Ru porcelain, Guan kiln, Tang San Cai, Nanyang jade carving, the wood engraving picture of Zhuxian town in Kaifeng, Tang Yin paper-cut, Junxian clay sculpture, Huaiyang mud mud dog. What's more, there are some folk handicrafts which more close to life such as the wickerwork in Yanjin County of Xinxiang City and the bamboo weaving in Boai County of Jiaozuo City and so on. Only in the case of the wood engraving picture of Zhuxian town in Kaifeng, the painted tiger and the guard on the front gate in Han Dynasty, the painted cock on the front gate in Wei and Jin Dynasty, including the Buddhist engravings in Sui and Tang Dynasty. These are the basis of the woodblock New Year paintings in Song Dynasty. After the Northern Song Dynasty, the woodblock New Year paintings in Zhuxian town were widely used. According to the Beautiful Dream Tokyo, in the capital of Northern Song Dynasty when the New Year is coming, New Year paintings are sold on every street. There are many other native folk handicrafts that have a long history in central plains. For example, the clay in Huaiyang and Jun County, in the present existence state, if there is no January meeting in the Jun County or no February meeting in Huaiyang, I'm afraid that the two ancient handicrafts are no longer there. Although the folk handicraft reserves in our province are abundant, according to the data, the current form is not optimistic. For a variety of reasons, the current management of rural handicraft in Henan province still has many unsatisfactory places. The main performances are in the following aspects:

First, the concept is lagging behind. The cultural departments in some areas are still using the thinking mode and management routines under the planned economy system to lead the rural cultural construction. Or engage in formalism, or rely entirely on government grants. The lagging management concept is seriously dislocated with the reality of rural social culture, which is out of line with the requirements of the rural masses, resulting in the passivity of some local rural cultural leadership institutions. 
Second, the management is disorderly. The coordination between the relevant departments is deficient. There are many management parties in case of "benefit". On the contrary, they will mutual buck passing. The more general situation is that there is no quantitative standard, with chaotic phenomena. These situations are particularly prominent in the face of handicraft products in the market and many handicraft products give up the traditional production process, blindly "copying". Not only rough products lose their taste, but also the skills handed down by ancestors are gradually dying. More attention should be paid to the fact that when the good and bad mixed handicraft products enter the market, consumers will gradually lose confidence.

Third, the organization is indulgent. In the present period of social transition, farmers are longing for a rich life. Migrant workers are far from their hometown. Many local rural cultural management works are in the state of laissez-faire. People left to themselves in the process of transformation from collective management to social management of handicraft industry in rural areas. The relaxation of management of leaderships led to the flow of a large number of rural craftsmen.

Fourth, some ideas are provisional in planning. The basic purpose of the new rural cultural construction is to comprehensively improve the ideological and moral quality and scientific and cultural quality of the peasants through cultural means, and to promote the overall progress of rural society. But the reality is that the individual leadership departments often consider less long-term interests, lack of strategic vision. In many places, "there are more activities and less construction." What's more, someone hurts the long-term interests in pursuit of immediate interests

\section{TO ENHANCE THE IMPORTANCE OF RURAL}

HANDICRAFTS FOR THE CONSTRUCTION OF NEW RURAL

\section{Culture in Henan}

Henan province is a big culture province, but it is necessary to realize that the whole population is mostly rural population. In the long-term accumulation of production and life, farmers form a typical style of handicraft art form. The cultural construction of rural areas in Henan province occupies a special and important position in the cultural construction of the province. Without the cultural construction of the countryside, the whole cultural construction of Henan province will be not complete and successful. The CPC Central Committee put forward that strengthen the construction of socialist new countryside revolution especially the construction of new rural culture need to be known with the height of the national strategy about the cultural competitiveness and cultural soft power, need to put it in the great cause of socialist construction with Chinese characteristics, need to known with the strategic thinking of exploring the law of the revival of Chinese culture and the law of the development of new socialist countryside.

\section{A. The Incessant Change of Farmers' Spiritual and Cultural Demands}

According to the survey, most farmers have a strong inherent desire for a variety of spiritual and cultural life.
Seeking for beauty, seeking pleasure, seeking knowledge, seeking for participation and seeking health are the common requirements of the broad masses of peasants. Thus, the demand for spiritual culture of the peasants who are on the road to well-off society is increasing. However, due to inadequate investment in the spiritual and cultural life of the relevant government departments in the rural cultural construction, cultural activities, venues and facilities are far from meeting the needs. Many farmers expressed their desire for cultural life, but they were helpless. Rural cultural construction is not suited to the spiritual and cultural needs of the peasants, there is still a big gap in the rural cultural market, and there is a big disparity between urban and rural cultural development.

\section{B. Farmers Need the Heritage and Influence of the Traditional Handicrafts}

Henan province is a famous historical and cultural province. Folk handicrafts are rich in depth and traditional handicraft resources are abundant. After a long period of historical precipitation, these art forms have been rooted in the vast countryside of Henan. The promotion of folk handicraft plays a decisive role in the construction of rural culture. Because handicraft is living in the daily life of the vast peasants, many peasants are attached to the idea of using handmade objects to convey feelings in some important occasions such as the wedding or funeral. All these things make them believe, learn quickly, and accept quickly. Skills like the wood engraving picture of Zhuxian town in Kaifeng, Huaiyang mud dog, willower work, paper-cut etc are original. The folk handicrafts with strong local flavor and regional characteristics make Henan culture charming, and become the spiritual wealth for peasants to enjoy for generations. These "living" handicrafts in life have condensed the wisdom of the masses of peasants in the change of history. For thousands of years, we have passed on the love and expectation of our forefathers for our children and grandchildren. In the long process of making and using these skills, farmers constantly strengthen their sense of identity and belonging to their ancestors, to their native land and to their cultural origin. These precious folk handicraft traditions are the root of our culture and the source of our culture. Strengthen the protection of folk handicraft is not only the preservation of a skill, what is more important is to keep the peasants' love and lookout for their native land.

\section{The State of Folk Handicrafts under the New Rural Construction Policy}

The construction of new rural culture promotes the selfhelp of peasant culture. The present situation of handicrafts and cultural situations in rural areas are two-fold. On the one hand, due to the backward cultural foundation of the countryside and the weak cultural autonomy, the backward cultural forms left behind by history are mostly in the countryside; on the other hand, the development of new countryside is the focus of socialist modernization. The present rural crafts are confronted with the grim situations of cultural competition, cultural infiltration and cultural security. This situation highlights the urgent need to accelerate the construction of new rural culture. Socialist new rural cultural construction represents the advanced socialist culture, which 
has the function of imparting and dominating social meaning and social thought, leading and integrating various social forces.

\section{THE PATH OF INHERITING AND BOOSTING HENAN HANDICRAFTS.}

\section{A. Raise the Awareness and Strengthen the Leadership}

"Insist on occupying the rural positions by socialist advanced culture to meet the farmers' growing spiritual and cultural needs and raise the ideological and moral quality of farmers". This is the general requirements in the "Decision" made on the third plenary session of the 17th central committee for the prosperity and development of current rural culture. Leaders at all levels should strengthen and attach great importance to the construction of rural culture. Establish the target responsibility system for the rural cultural services of the county (district), town and village level, culture, health, political law, education, technology, radio and television and other fields and departments should be managed, constructed and shared together.

\section{B. Adapt to the Demand of Rural Culture, Make a MultipleDevelopment of Spiritual Culture Products}

At present, the popular cultural activity has become the main channel for the rural masses to enjoy modern life, but the activity is less, the channel is narrow and the form is old. This becomes the dilemma of this kind of activity. Taking rural life as the theme, reflecting the real life of farmers, the spiritual and cultural products which farmers love are less and less. Relevant departments should strongly support the areas with the conditions to form special cultural brands and develop rural cultural industries. Such as excavating local food culture, folk paper cutting, flower arranging, handicraft production, and other resources. In addition, traditional festivals and temple fairs can be used as the starting point to organize various timely forms of cultural activities suitable for the broad masses of farmers. We can also support the conditional region to carry out unique "one place and one product" form to build community cultural brand activities. Preferential policies should be formulated to improve the healthy cultural consumption in rural areas through the reduction of taxes and fees in the rural areas, such as bookstores, chess and cards rooms, billiards rooms, and arts group activities carried out in rural areas. Set awards to encourage the literary works which taking farmers as the service object.

\section{Increase Investment in Rural Cultural Infrastructure Construction}

In many places, the cultural activity places and facilities is deficient that has led to the lack of "blood production" in rural culture. The investment is made mainly in the district (county) and township that "depending on financial support". The local government should seriously study how to solve the problem of insufficient funds for the basic cultural undertakings under the existing fiscal and taxation system. At the same time, we should realize that the construction of rural culture should not rely solely on government investment. In addition to establishing a government investment guarantee mechanism, we should also formulate diversified preferential policies to guide and encourage social groups, private enterprises and wealthy individuals to invest in rural cultural undertakings or to contribute to public welfare cultural undertakings. We will provide more financial support for the construction of cultural facilities and cultural activities in town and village through naming sponsorship and joint activities and build a new and multi-channel investment system for rural cultural construction to strengthen the foundation of rural cultural construction and meet the spiritual and cultural needs of farmers.

\section{To Find and Develop Ethical Folk Culture, Carry forward National Culture}

Excellent folk traditional culture is an important part of Chinese civilization. Because of the strong local flavor and regional characteristics, it has become an important foundation for the construction of new rural culture. Those old folk artists who stay in the countryside are the people who are familiar with the local folk culture. They are familiar with the reality of rural life, and can attract and encourage the peasants around them to participate in various cultural activities proactively. We must make them start to organize, carry out cultural festival and related activities, mine their organization and guidance ability, so that they become the backbone of the team of rural cultural construction, so as to improve the participation rate of rural cultural activities. In order to make rural cultural activities become a kind of mass cultural activities, to broaden the popularization of new rural cultural construction. In this way, the unique folk culture, traditional art and popular activities on farmers in rural areas can meet the farmers from blossom to satisfy the spiritual cultural pursuit of selfappreciation, self-entertainment and self-development for peasants. National folk culture also contains important economic value, especially non-material cultural heritage, which will play an active role in the development of new rural economy through exploitation and utilization. Therefore, we should increase the publicity of folk traditional culture and other means to explore and protect the national folk culture, so as to make the excellent traditional culture in line with each other, and bring people together.

\section{CONCLUSION}

The inheritance of folk culture is involved with the public cause of ethnic group and the whole society, which needs the interaction of the country and the people. What's more, we need a rational and healthy cultural mindset and cultural environment to face the history, reality and future. The education inheritance of folk culture is not only a process that the folk culture resources enter the mainstream education after ignored for a long time, and a continuation of the ancient life memory. At the same time, it is also a cognitive process of national survival spirit and survival wisdom and living culture. It is a process of national cultural integration with more human discovery and rational spirit. Cultural construction is an important part of the construction of new socialist countryside. It is the soft power of new rural construction. The rapid economic development must also require a flourishing culture together. To do a good job in rural culture construction, we must constantly use the socialist advanced culture to take the 
rural positions and further pay attention to farmers' cultural demand, and then through a variety of ways and means to meet their increased spiritual and cultural demands and make rural culture prosperous. This is an important content to greatly promote cultural development and prosperity, and also an inevitable requirement to boost the construction of new socialist countryside.

\section{REFERENCES}

[1] Dang Chunzhi Folk arts and crafts in Central Plains[M]. Zhengzhou: Henan people's publishing house, 2006.

[2] Wang Qingbin. Advantages of developing traditional arts and crafts industry in Henan and its role in regional economy[J]. Eco economy, 2008(9):

[3] Deng Mingyan, Luo Jiaming. The interaction between the protection and utilization of world heritage and community development in Britain: such as the Hadrian Great Wall [J]. Eco economy, 2007 (12) : 141145 .

[4] Zhou Bo. Dialogue and listening: the inheritance and development of traditional handicraft in contemporary context $[\mathrm{J}]$. Journal of Nanjing Arts Institute,2012(6): 061-065.

[5] Li Yanzu. Introduction of arts and crafts[M]. Beijing, China light industry press, 1999:211.

[6] Sun Yingchun. An introduction of intercultural communication[M]. Beijing, Peking University press,2008:274. 